\title{
Immunocytochemical demonstration of oestrogen receptor $\beta$ in blood vessels of the female rat
}

\author{
C Andersson ${ }^{1}$, M-L Lydrup, M Fernö ${ }^{2}$, I Idvall ${ }^{1}$, J-Å Gustafsson ${ }^{3}$ \\ and B-O Nilsson \\ Department of Physiological Sciences, Lund University, BMC F12, S-221 84 Lund, Sweden \\ ${ }^{1}$ Department of Pathology, Lund University Hospital, S-221 85 Lund, Sweden \\ ${ }^{2}$ Department of Oncology, Lund University Hospital, S-221 85 Lund, Sweden \\ ${ }^{3}$ Department of Medical Nutrition, Karolinska Institute, Novum, S-141 86 Huddinge, Sweden \\ (Requests for offprints should be addressed to B-O Nilsson; Email: Bengt-Olof.Nilsson@mphy.lu.se)
}

\begin{abstract}
The role of oestrogen receptor (ER) $\beta$ in vascular function remains unclear. With the use of a specific ER $\beta$ antibody we have now, using immunocytochemistry, visualized ER $\beta$ in different parts of the vascular tree. In about $70 \%$ of medial smooth muscle cells of female rat aorta, tail artery and uterine artery, nuclear immunoreactivity to $\operatorname{ER} \beta$ was observed. In these vessels endothelial cells also expressed $\operatorname{ER} \beta$. Vascular expression of the $\mathrm{ER} \alpha$ subtype was lower than that of ER $\beta$. In aorta and tail artery, no immunoreactivity towards $\mathrm{ER} \alpha$ was observed, while in uterine vessels occasional medial smooth muscle and endothelial cells expressed this ER subtype. ER $\beta$ and $\alpha$ expression in uterine vessels was independent of the stage of the oestrous cycle, suggesting that variations in uterine blood flow
\end{abstract}

occurring during the cycle are independent of ER density. The regional distribution of ER $\alpha$, as determined by immunocytochemistry, was supported by measurements of ER $\alpha$ levels by enzyme immunoassay. In the uterine artery, the level of ER $\alpha$ was several times higher $(P<0 \cdot 001)$ than that of aorta and tail artery $(10 \cdot 1 \pm 1.7 \mathrm{fmol} / \mathrm{mg}$ protein in the uterine artery vs $3.3 \pm 1.0$ and $0.5 \pm 0.5 \mathrm{fmol} / \mathrm{mg}$ protein in aorta and tail artery respectively). Thus, a prominent nuclear expression of ER $\beta$ was observed in the vascular wall of several parts of the vascular tree, while $\mathrm{ER} \alpha$ predominantly was expressed in uterine vessels, suggesting that ER $\beta$ and $\alpha$ may have different roles in vascular function.

Journal of Endocrinology (2001) 169, 241-247

\section{Introduction}

Oestrogen receptors (ER) are divided into subtypes $\alpha$ and $\beta$ (Green et al. 1986, Greene et al. 1986, Kuiper et al. 1996). ER $\beta$ cDNA shows some highly homologous domains with ER $\alpha$ cDNA. The overall homology between ER $\alpha$ and $\beta$ is approximately $50 \%$. Prominent expression of ER $\beta$ mRNA, as determined by RT-PCR, has been shown in rat prostate, ovary, epididymis, testis, bladder, uterus, lung, colon, small intestine and brain (Kuiper et al. 1996, 1997). ER $\beta$ has been visualized in many of these tissues by immunocytochemistry (Saunders et al. 1997, Pelletier et al. 2000). Cell-specific localization of ER $\alpha$ and $\beta$ in the reproductive tract of male and female rats has been reported by Pelletier et al. (2000). In a recent paper, Saji et al. (2000) showed, using immunocytochemistry, that ER $\alpha$ as well as ER $\beta$ are expressed in the nuclei of glandular epithelial cells of the rat mammary gland. ER $\alpha$ expression varies substantially during breast development from as low as $5 \%$ of cell nuclei at day 14 of pregnancy to $70 \%$ at day 21 of lactation, while the expression of $\beta$ was constant (60-70\% of cell nuclei) during all stages of breast development.

Binding sites for oestrogen have been shown in different vascular preparations using radioligand binding (Farhat et al. 1996, Freay et al. 1997). ER $\alpha$ has been visualized, using immunocytochemistry, in rat aortic smooth muscle cells (Orimo et al. 1993) and in guinea pig, rabbit and human uterine arteries (Perrot-Applanat et al. 1988, Leiberman et al. 1990). In some other vascular segments, i.e. carotid artery and aorta of the guinea pig, Leiberman et al. (1990), however, observed no immunoreactivity towards ER $\alpha$, suggesting that this receptor is regionally distributed within the vascular system. Human vascular smooth muscle cells have also been shown to contain ER $\alpha$ (Karas et al. 1994).

Vascular expression of mRNA for $\operatorname{ER} \beta$ has been shown in rat aorta and carotid artery and in mouse aorta (Iafrati et al. 1997, Lindner et al. 1998, Mäkelä et al. 1999). After vascular injury, the expression of $E R \beta$ is increased (Lindner et al. 1998, Mäkelä et al. 1999). The purpose of the present study was to visualize, by 
immunocytochemistry, vascular ER $\beta$ using a specific antibody. Interestingly, we have observed an abundant vascular expression of ER $\beta$, while ER $\alpha$ was predominantly expressed in uterine vessels.

\section{Materials and Methods}

\section{Animals and tissues}

Adult (3-month-old) female Sprague-Dawley rats, weighing $200 \mathrm{~g}$, were used. The animals were kept on a standard laboratory animal diet with water available ad libitum and under constant light $(0700-2100 \mathrm{~h})$. The rats were killed by cervical dislocation. The animal handling was approved by the Animal Ethics Committee at Lund University. Thoracic aorta, tail artery, uterine artery and uterus were dissected free from fat and connective tissue under a dissecting microscope in $\mathrm{Ca}^{2+}$-free Krebs solution of the following composition (in $\mathrm{mM}$ ): $\mathrm{NaCl} 122, \mathrm{KCl} 4 \cdot 7$, $\mathrm{NaHCO}_{3} 15 \cdot 5, \mathrm{KH}_{2} \mathrm{PO}_{4} 1 \cdot 2, \mathrm{CaCl}_{2} 2 \cdot 5, \mathrm{MgCl}_{2} 1 \cdot 2$ and glucose 11.5. After dissection the tissues were carefully washed in buffer.

\section{Immunocytochemistry}

Tissue specimens were fixed in $4 \%$ buffered formalin solution, dehydrated and then embedded in paraffin. The preparations were cut in $4 \mu \mathrm{m}$ sections transversely and longitudinally, deparaffinized and treated for $15 \mathrm{~min}$ with citrate buffer $(\mathrm{pH} 6.0)$ in a microwave oven before the immunostaining (Shi et al. 1991). The primary antibodies used were a specific ER $\alpha$ antibody (monoclonal mouse ER $\alpha$ antibody, ER1D5; DAKO A/S, Glostrup, Denmark) at a dilution of 1:100 (Pettersson et al. 1997) and a specific antibody against ER $\beta$ (ER $\beta 503$ antibody), raised in chickens at dilutions of 1:750, 1:1000 or 1:1500 as indicated (Saji et al. 2000). In preliminary experiments, the dilutions of the primary antibodies were titrated in each tissue to achieve optimal nuclear staining with minimal unspecific staining. The slides were stained in an automatic immunostainer TechMate 500 (Ventana Biotek, Tuscon, AZ, USA) with DAKO ChemMate Detection Kit peroxidase/3-3' diaminobenzidine. For ER $\beta$, the secondary antibody was a biotinylated rabbit anti-chicken IgY (1:5000; Jackson Immuno Research Laboratories, West Grove, PA, USA). Counterstaining to delineate nuclei was performed by dipping the slides in Mayer's haematoxylin for $20 \mathrm{~s}$. At each staining a positive control (breast tissue), expressing both ER subtypes (Saji et al. 2000), was run in parallel. Preabsorbed ER $\beta$ antibodies were obtained by incubating the antibody with the ER $\beta$ protein (50-fold excess of the protein) employed as antigen at $4{ }^{\circ} \mathrm{C}$ for $12 \mathrm{~h}$. For negative controls, the primary antibodies (anti-ER $\alpha$ and $\beta$ ) were omitted. In these different types of control stainings no immunoreactivity was observed. Tissues for immunocytochemistry were obtained from eleven rats and at least two staining slides were analyzed for each individual tissue and protein (ER $\alpha$ or $\beta)$.

\section{Determination of ERa using enzyme immunoassay}

For quantitative determination of ER $\alpha$ samples (at least $15 \mathrm{mg}$ ) of aorta, tail artery and uterine artery consisting of all three layers (tunica intima, tunica media and tunica adventitia) and uterus from 14 rats were homogenized with a microdismembrator, after which the powder was dissolved in buffer (10 mM Tris, $1.5 \mathrm{mM}$ EDTA, $5.0 \mathrm{mM}$ $\mathrm{Na}_{2} \mathrm{MoO}_{4}, 1.0 \mathrm{mM}$ monothioglycerol, $\mathrm{pH} 7 \cdot 4$ ). In order to increase the amount of tissue for accurate measurements, tail artery and uterine arteries from two rats were pooled. The homogenate was then centrifuged at $100000 \mathrm{~g}$ for $60 \mathrm{~min}$ at $0{ }^{\circ} \mathrm{C}$, whereafter the content of $\mathrm{ER} \alpha$ in the supernatant was measured with an enzyme immunoassay according to the kit instructions (Abbott Laboratories, Diagnostic Division, Chicago, IL, USA). The Abbott antibody is a rat monoclonal antibody (Greene et al. 1980) which recognizes ER $\alpha$ but not $E R \beta$. Uterine tissue, which has been reported to have high expression of ER $\alpha$ (Kuiper et al. 1997), was used as a positive control. The sensitivity of the Abbott ER $\alpha$ enzyme immunoassay monoclonal system is approximately $1.5 \mathrm{fmol} \mathrm{ER} \alpha / \mathrm{ml}$ and values below this were considered to be below the detection limit. ER $\alpha$ content was expressed as fmol $\mathrm{ER} \alpha / \mathrm{mg}$ protein. Protein was determined as described by Lowry et al. (1951), using bovine serum albumin as standard.

\section{Statistics}

Values are presented as means \pm S.E.M. ANOVA and Student's two-tailed $t$-test for unpaired comparisons were used to determine statistical significance. $P$ values less than 0.05 were regarded as denoting statistical significance.

\section{Results}

Nuclear immunoreactivity to ER $\beta$ was observed in numerous medial smooth muscle cells in aorta, tail artery and the uterine artery (Fig. 1A-C). In these three vessels, about $70 \%$ of the medial cells expressed ER $\beta$. In the vessels, ER $\beta$ immunoreactivity was also observed in endothelial cells. Breast tissue was used as a positive control and processed in parallel. In sections of breast tissue, nuclear staining with $E R \beta$ was observed in glandular epithelial cells (Fig. 1D). These cells also showed immunoreactive nuclear staining towards ER $\alpha$ (Fig. $4 \mathrm{H}$ ). The specificity of the ER $\beta$ antibody was investigated by inactivating antiserum with the antigen. No ER $\beta$ immunoreactivity was observed in sections stained with 

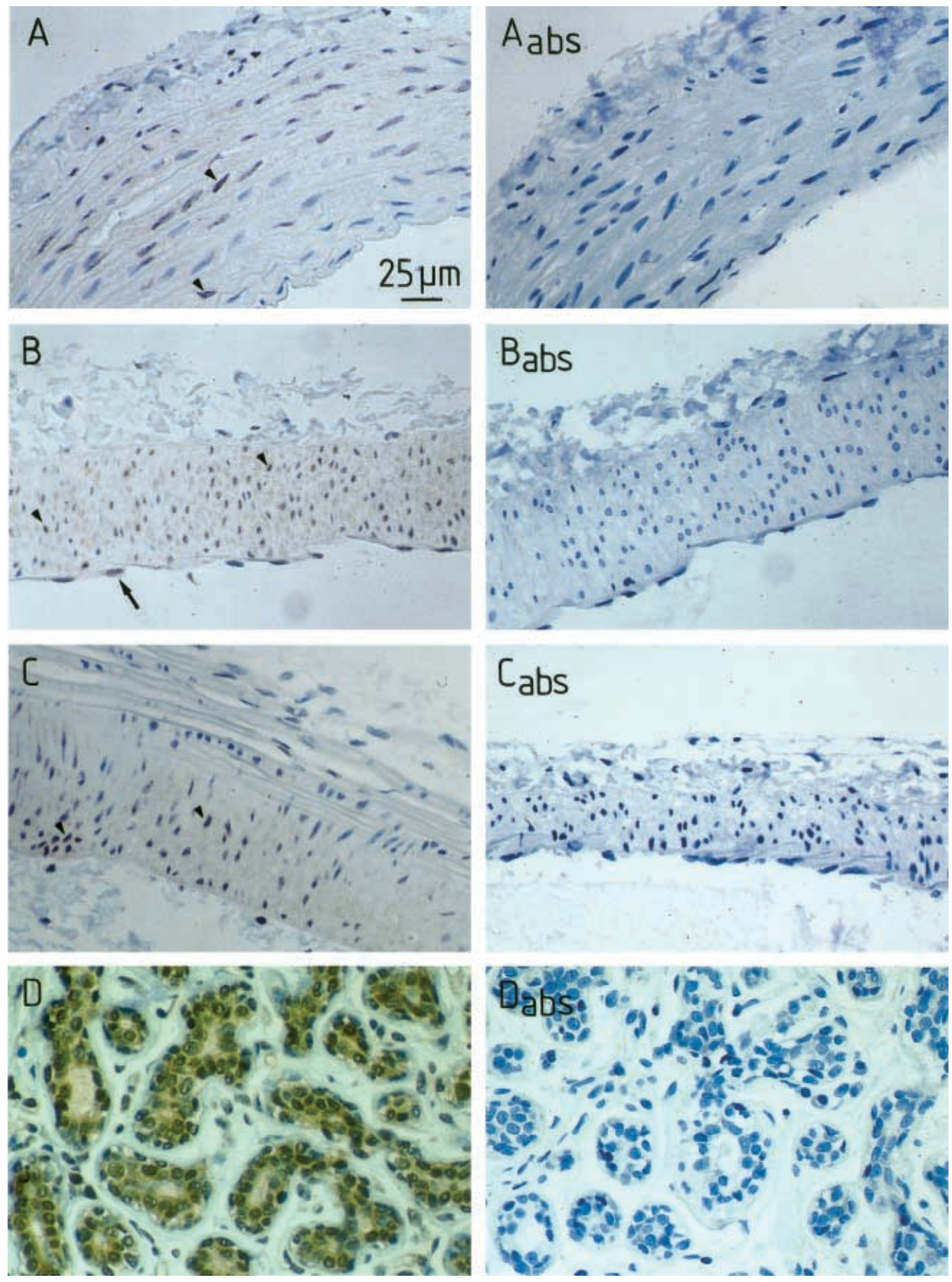

Figure 1 Immunocytochemical staining of longitudinal sections of aorta (A), tail artery (B) and uterine artery (C) with ER $\beta$ antibody (ER $\beta 503$ antibody, 1:1000). In (D) a section of breast tissue stained with ER $\beta$ antibody as a positive control is shown. On the right-hand side, stainings of consecutive tissue sections with preabsorbed antibody $\left(A_{a b s}-D_{a b s}\right)$ are shown. Specific nuclear immunostaining was observed in the medial smooth muscle cells of the vascular preparations and in the glandular epithelium of the breast tissue. (A-C) Arrowheads show examples of positive nuclei of medial smooth muscle cells. As shown by the arrow in (B) occasional ER $\beta$-positive endothelial cells could be observed. Endothelial cells were sometimes lost during preparation of tissue sections and staining. This occurred independently of the type of vessel. Bar in $(A)=25 \mu \mathrm{m}$ (for A-D). 

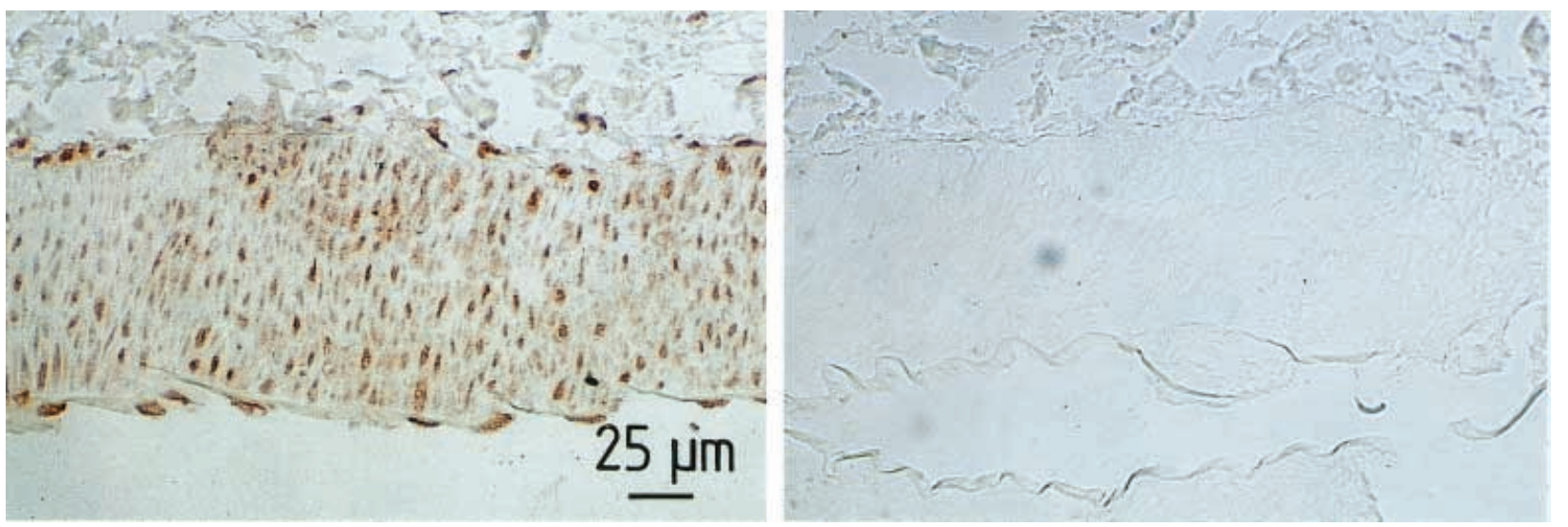

Figure 2 Immunocytochemical staining of a longitudinal section of tail artery with ER $\beta$ antibody (1:750) in the absence of nuclear counterstaining with Mayer's haematoxylin. Numerous positively stained smooth muscle and endothelial cells can be seen. No immunoreactivity was observed after staining with inactivated antiserum (right-hand side). Bar $=25 \mu \mathrm{m}$.

the inactivated antiserum (Fig. $1 \mathrm{~A}_{\mathrm{abs}}-\mathrm{D}_{\mathrm{abs}}$ ). In Fig. 2, a section of tail artery stained with ER $\beta$ antibody in the absence of nuclear counterstaining is shown. By omitting counterstaining, ER $\beta$ immunoreactive material within the nucleus of smooth muscle and endothelial cells was more prominent. No immunoreactivity was observed after staining with inactivated antiserum (Fig. 2, right-hand side).

In aorta and tail artery, no immunoreactivity to ER $\alpha$ was observed, while in the uterine vessels occasional medial smooth muscle and endothelial cells expressed the receptor (see below). Results obtained by enzyme immunoassay using a specific $\mathrm{ER} \alpha$ antibody supported the regional distribution of $\mathrm{ER} \alpha$ observed by immunocytochemistry (Fig. 3). The enzyme immunoassay was performed on homogenates of aorta, tail artery and uterine artery. The vascular preparations consisted of all three vessel wall layers, i.e. tunica intima, tunica media and tunica adventitia, and the amount of ER $\alpha$ was normalized to total protein content. As shown in Fig. 3, the uterine artery contained 3 and 20 times higher $(P<0 \cdot 001)$ levels of ER $\alpha$ compared with aorta and tail artery respectively. Homogenate of rat uterus was used as a positive control. The uterine tissue contained about 10 times higher $(P<0 \cdot 001)$ levels of ER $\alpha$ than the uterine artery $(112 \pm 18$ vs $10 \cdot 1 \pm 1.7 \mathrm{fmol} / \mathrm{mg}$ protein).

In order to determine $\operatorname{ER} \beta$ and $\alpha$ in uterine vessels, sections of uterus were prepared and immunostained for ER subtypes. In Fig. 4 immunostainings made on tissues collected at dioestrus are presented. The stage of cycle was monitored cytologically by vaginal smears. After two regular cycles, animals were killed at pro-oestrus, oestrus, metoestrus and dioestrus and tissues collected. Positive nuclear immunoreactive staining for $\operatorname{ER} \beta$ and $\alpha$ was observed in vascular smooth muscle cells of arterioles (Fig. 4A and E). Occasional endothelial cells showed positive staining for ER $\beta$ and $\alpha$. In uterine vessels, no differences in $\operatorname{ER} \beta$ expression with the stage of the oestrous cycle were observed. Vascular ER $\alpha$ expression was also independent of the stage of the cycle.

Immunoreactivity towards ER $\alpha$ was observed in $80 \%$ of the nuclei of glandular epithelial cells (Fig. 4F). In contrast to the strong ER $\alpha$ expression, ER $\beta$ was only weakly

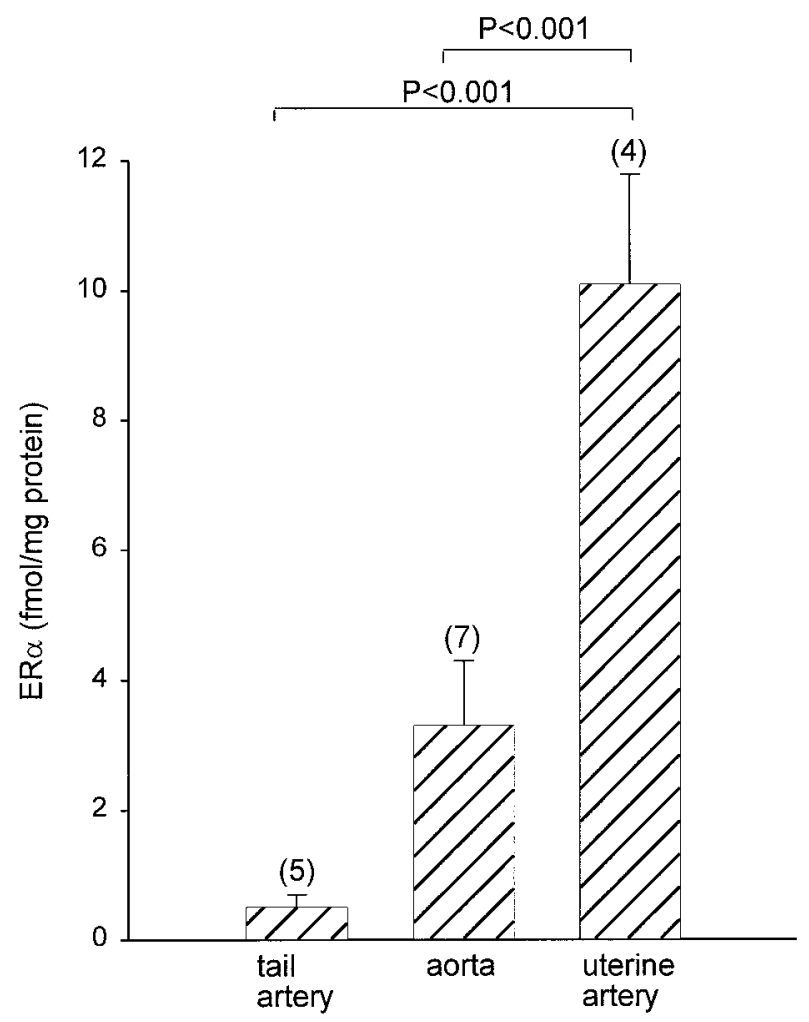

Figure 3 Amount of $\mathrm{ER} \alpha$ ( $\mathrm{fmol} / \mathrm{mg}$ protein) in tail artery, aorta and uterine artery determined by enzyme immunoassay. The numbers of observations are given in brackets. 

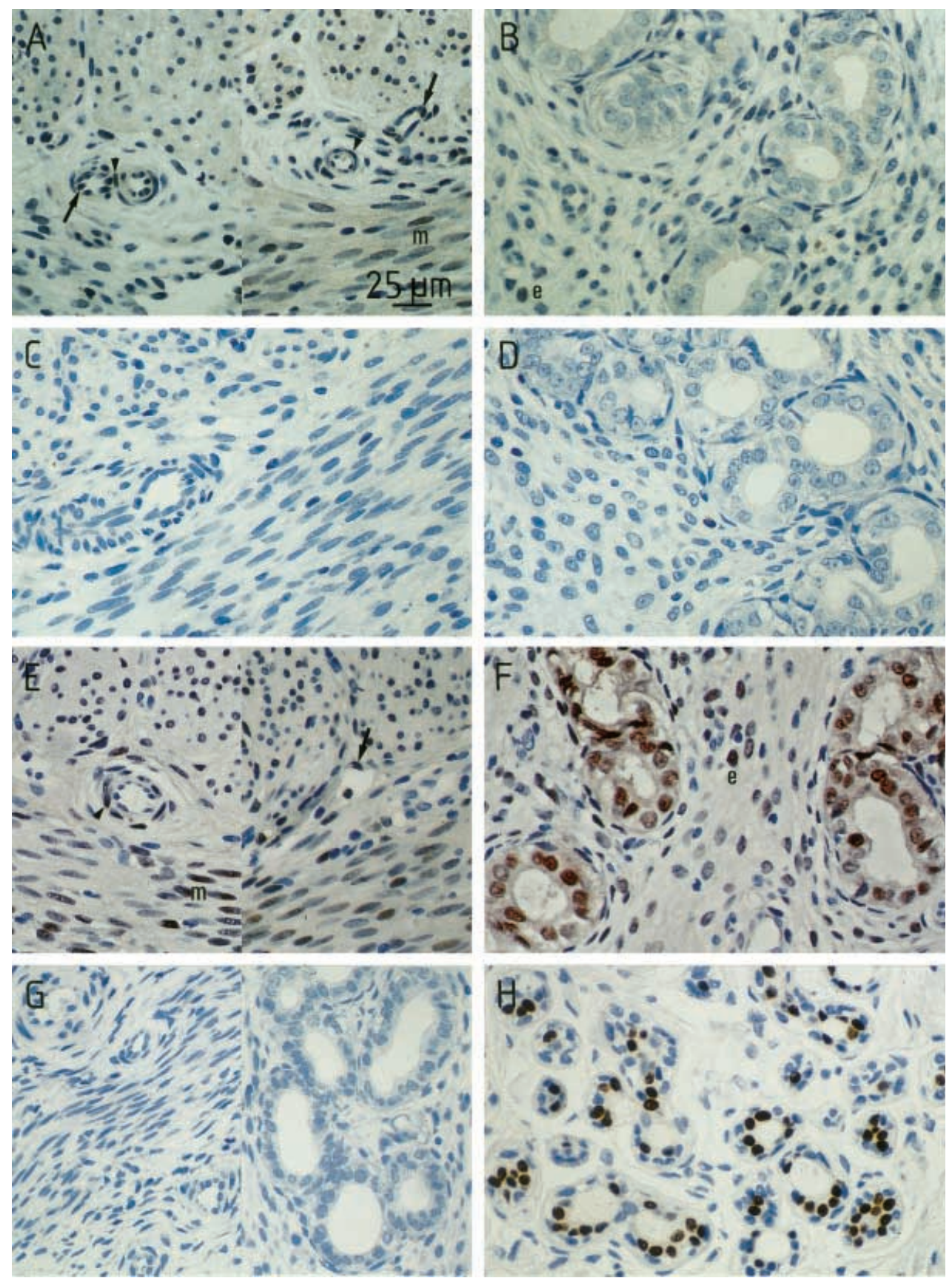

Figure 4 Immunocytochemical staining of consecutive transverse sections of uterus at dioestrus with ER $\beta$ (A and $B, 1: 1500$ ) and $E R \alpha$ ( $E$ and $F, 1: 100)$ antibodies. In (A and $E$ ) segments with uterine vessels are shown. Note ER $\beta$ - and ER $\alpha$-positive vascular smooth muscle (arrowheads) and endothelial cells (arrows). A majority of myometrial smooth muscle cells $(\mathrm{m})$ show immunoreactive staining towards ER $\beta$ and $\alpha$. In (B and F) segments in the endometrium with uterine glands are shown. A majority of the glandular epithelial cells contained nuclear immunoreactivity towards ERa (F), while only a fraction of these cells contained nuclear ER $\beta$ immunoreactive material (B). Immunoreactivities towards ER $\beta$ as well as ER $\alpha$ were observed in the stroma cells of the endometrium (e). In (C and D) consecutive sections of uterine vessels and uterine glands stained with preabsorbed ER $\beta$ antibody are shown. No immunostaining was observed after preabsorbtion of the ER $\beta$ antibody. No immunoreactivities were observed either in vessels (left-hand side) or glands (right-hand side) if the primary ER $\alpha$ antibody was omitted $(\mathrm{G})$. (H) Breast tissue stained with ER $\alpha$ as a positive control. Bar in $(\mathrm{A})=25 \mu \mathrm{m}$ (for $\mathrm{A}-\mathrm{H})$. 
expressed $(<10 \%$ of the cells) in these cells (Fig. 4B). In the smooth muscle cells of the myometrium, about $70 \%$ of the cells expressed nuclear ER $\beta$ and ER $\alpha$ (Fig. 4A and E). About the same number of endometrial stroma cells showed nuclear immunoreactivity towards $\operatorname{ER} \beta$ and $\alpha$ (Fig. 4B and F). Glandular epithelial, myometrial smooth muscle and endometrial stroma cells expressed $\operatorname{ER} \beta$ and $\alpha$ at all stages of the oestrous cycle. No immunostaining was observed if the ER $\beta$ antibody was preabsorbed with antigen (Fig. 4C and D) or if the ER $\alpha$ antibody was omitted (Fig. 4G)

\section{Discussion}

In this study, we have visualized ER $\beta$ protein in vascular smooth muscle cells from three different parts of the vascular tree in the female rat. Almost $70 \%$ of the medial cells independent of vessel type expressed nuclear ER $\beta$, indicating that ER $\beta$ mediates the transcriptional effects of oestrogen in the whole vascular tree and not only in specific segments.

Our results suggest that $\mathrm{ER} \alpha$, in contrast to $\operatorname{ER} \beta$, is predominantly expressed in certain vascular beds, e.g. the uterine vessels. In the tail artery and in the aorta, low levels of $E R \alpha$ were observed compared with the uterine artery. In endothelial cells, physiological concentrations (nM) of oestrogen enhance the production of nitric oxide within minutes and further cause a translocation of endothelial nitric oxide synthase (eNOS) from the plasma membrane to intracellular sites close to the nucleus (Lantin-Hermoso et al. 1997, Chen et al. 1999, Goetz et al. 1999). The rapid induction of eNOS is ER dependent since it is blockable by ER antagonists and it has been reported to be dependent on ER $\alpha$ activation (Chen et al. 1999). Thus, one could speculate that this mechanism is more pronounced in regions of the vascular tree rich in $E R \alpha$, e.g. in the uterine artery, than in regions with low ER $\alpha$ expression.

The available evidence suggests that oestrogens mediate the increase in uterine blood flow occurring in pregnancy and during the oestrous cycle (Markee 1932, Greiss \& Anderson 1970, Killam et al. 1973, Rosenfeld 1989). The mechanism(s) responsible for oestrogen-induced elevated blood flow remain, despite much effort, unclear (Mendelsohn \& Karas 1999). Increases in uterine blood flow by $17 \beta$-oestradiol are prevented by the NOS inhibitor nitro-L-arginine methyl ester, suggesting that nitric oxide is involved (Van Buren et al. 1992, Rosenfeld et al. 1996). However, other vasoactive substances, such as prostanoids and vasoactive polypeptides have also been implicated (Killam et al. 1973, Clark et al. 1981a,b). Here, we report that both ER $\beta$ and $\alpha$ are expressed in uterine vessels and thus both receptors may be involved in the regulation of uterine blood flow by oestrogens. No changes in uterine vessel $\operatorname{ER} \beta$ and $\alpha$ expression were observed during the oestrous cycle, suggesting that mechanisms other than ER density are important.
In the present study, we report a cell-specific nuclear distribution of $\operatorname{ER} \alpha$ and $\beta$ in uterus. Both subtypes are expressed in myometrial smooth muscle cells, endometrial stroma cells and in the vascular wall of uterine vessels. In glandular epithelial cells, on the other hand, intense immunoreactivity towards ER $\alpha$ was observed in a majority of cells, while ER $\beta$ immunoreactivity was much weaker and only occurred in a few cells. This suggests that oestrogen exerts its effect on uterine glandular function mainly through activation of ER $\alpha$. In a recent study, Taylor \& Al-Azzawi (2000) have reported a similar cellular distribution pattern of ER subtypes in human uterus. The isoflavone phyto-oestrogen genistein, which has 20 times higher binding affinity for ER $\beta$ than for ER $\alpha$ has been shown to exert a vasculoprotective effect after vascular injury but not a uterotrophic effect, while an unselective ER agonist like $17 \beta$-oestradiol has both a vasculoprotective and a uterotrophic effect (Mäkelä et al. 1999). After balloon injury, expression of ER $\beta$ mRNA in male rat aorta and carotid artery is increased in endothelial as well as smooth muscle cells, while the expression of ER $\alpha$ mRNA remains at a low level (Lindner et al. 1998, Mäkelä et al. 1999). The tissue selective effect of genistein may thus be explained by differences in $\operatorname{ER} \beta$ expression.

In breast glandular epithelial cell nuclei from the rat, ER $\alpha$ expression is decreased at puberty and at pregnancy compared with at prepuberty (Saji et al. 2000). During lactation, a large induction of ER $\alpha$ is observed with $70 \%$ of cell nuclei showing positive immunostaining. This suggests that ER $\alpha$ expression is not governed by the elevated level of oestrogen occurring during puberty and pregnancy but through other hormonal mechanisms. ER $\beta$ expression seems to be independent of hormonal status since it stays constant $(60-70 \%$ of glandular cell nuclei) during all phases of breast development. It is interesting to note that expression of ER $\beta$ in breast glandular cells is quantitatively similar to vascular smooth muscle cell expression of ER $\beta$, suggesting that this ER subtype is important in both of these cell types.

The most striking finding in the present study was the abundant vascular expression of ER $\beta$. The role of ER $\beta$ in vascular function has been addressed in a few studies but has not been explained. In the ER $\beta$ knock-out mice (BERKO), vascular morphology and force responses to noradrenaline are unaltered, suggesting that $\operatorname{ER} \beta$ is not crucial for vascular development (Nilsson et al. 2000). Oestrogen inhibits the response to vascular injury in wild-type, ER $\alpha$ knock-out (ERKO) as well as in BERKO mice, suggesting that $\operatorname{ER} \alpha$ and ER $\beta$ may both mediate vascular protection by oestrogen in a redundant manner or that a third mechanism exists for oestrogen-dependent vascular protection (Iafrati et al. 1997, Karas et al. 1999). The challenge for the future must be to investigate the importance of vascular ER $\beta$ further. 


\section{Acknowledgements}

This study was supported by the Swedish Medical Reserach Council (grant no. K99-04X-13017-01A), the Swedish Heart and Lung Foundation and the foundations of Åke Wiberg and Magnus Bergvall as well as by the Swedish Cancer Fund and KaroBio AB.

\section{References}

Chen Z, Yuhanna IS, Galcheva-Gargova Z, Karas RH, Mendelsohn ME \& Shaul PW 1999 Estrogen receptor $\alpha$ mediates the nongenomic activation of endothelial nitric oxide synthase by estrogen. Journal of Clinical Investigation 103 401-406.

Clark KE, Austin JE \& Stys SJ 1981a Effect of bisenoic prostaglandins on the uterine vasculature of the nonpregnant sheep. Prostaglandins 22 333-348.

Clark KE, Mills EG, Stys SJ \& Seeds AE $1981 b$ Effects of vasoactive polypeptides on the uterine vasculature. American Journal of Obstetrics and Gynecology 139 182-188.

Farhat MY, Lavigne MC \& Ramwell PW 1996 The vascular protective effects of estrogen. FASEB Journal 10 615-624.

Freay AD, Curtis SW, Korach KS \& Rubanyi GM 1997 Mechanism of vascular smooth muscle relaxation by estrogen in depolarized rat and mouse aorta. Circulation Research 81 242-248.

Goetz RM, Thatte HS, Prabhakar P, Cho MR, Michel T \& Golan DE 1999 Estradiol induces the calcium-dependent translocation of endothelial nitric oxide synthase. PNAS 96 2788-2793.

Green S, Walter P, Kumar V, Krust A, Bornert J-M, Argos P \& Chambon P 1986 Human oestrogen receptor cDNA: sequence, expression and homology to v-erb-A. Nature 320 134-139.

Greene GL, Nolan C, Engler JP \& Jensen EV 1980 Monoclonal antibodies to human estrogen receptor. PNAS 77 5115-5119.

Greene GL, Gilna P, Waterfield M, Baker A, Hort Y \& Shine J 1986 Sequence and expression of human estrogen receptor complementary DNA. Science 231 1150-1154.

Greiss FC Jr \& Anderson SG 1970 Effect of ovarian hormones on the uterine vascular bed. American Journal of Obstetrics and Gynecology $107829-836$

Iafrati MD, Karas RH, Aronovitz M, Kim S, Sullivan TR Jr, Lubhan DB, O’Donnell TF Jr, Korach KS \& Mendelsohn ME 1997 Estrogen inhibits the vascular injury response in estrogen receptor $\alpha$-deficient mice. Nature Medicine 3 545-548.

Karas RH, Patterson BL \& Mendelsohn ME 1994 Human vascular smooth muscle cells contain functional estrogen receptor. Circulation 89 1943-1950.

Karas RH, Hodgin JB, Kwoun M, Krege JH, Aronovitz M, Mackey W, Gustafsson J-Å, Korach K, Smithies O \& Mendelsohn ME 1999 Estrogen inhibits the vascular injury response in estrogen receptor $\beta$-deficient female mice. PNAS 96 15133-15136.

Killam AP, Rosenfeld CR, Battaglia FC, Makowski EL \& Meschia G 1973 Effects of estrogens on the uterine blood flow of oophorectomized ewes. American Journal of Obstetrics and Gynecology $1151045-1052$.

Kuiper GGJM, Enmark E, Pelto-Huikko M, Nilsson S \& Gustafsson J-Å 1996 Cloning of a novel estrogen receptor expressed in rat prostate and ovary. PNAS 93 5925-5930.

Kuiper GGJM, Carlsson B, Grandien K, Enmark E, Häggblad J, Nilsson S \& Gustafsson J-Å 1997 Comparison of the ligand binding specificity and transcript tissue distribution of estrogen receptors $\alpha$ and $\beta$. Endocrinology 138 863-870.

Lantin-Hermoso RL, Rosenfeld CR, Yuhanna IS, German Z, Chen Z \& Shaul PW 1997 Estrogen acutely stimulates nitric oxide synthase activity in fetal pulmonary artery endothelium. American Journal of Physiology 273 L119-L126.
Leiberman JR, van Vroonhoven CCJ, Beckman I, van der Kwast TH \& Wallenburg HCS 1990 Uterine artery estrogen receptors in the nonpregnant and pregnant guinea pig. American Journal of Obstetrics and Gynecology 163 1685-1688.

Lindner V, Sung KK, Karas RH, Kuiper GGJM, Gustafsson J-Å \& Mendelsohn ME 1998 Increased expression of estrogen receptor- $\beta$ mRNA in male blood vessels after vascular injury. Circulation Research 83 224-229.

Lowry OH, Rosebrough NJ, Farr AL \& Bandall RJ 1951 Protein measurement with the Folin phenol reagent. Journal of Biological Chemistry 193 265-275.

Mäkelä S, Savolainen H, Aavik E, Myllärniemi M, Strauss L, Taskinen E, Gustafsson J-Å \& Häyry P 1999 Differentiation between vasculoprotective and uterotrophic effects of ligands with different binding affinities to estrogen receptors $\alpha$ and $\beta$. PNAS 96 7077-7082.

Markee JE 1932 Rhythmic vascular changes. American Journal of Physiology 100 32-39.

Mendelsohn ME \& Karas RH 1999 The protective effects of estrogen on the cardiovascular system. New England Journal of Medicine 340 1801-1811.

Nilsson B-O, Ekblad E, Heine T \& Gustafsson J-Å 2000 Increased magnitude of relaxation to oestrogen in aorta from oestrogen receptor $\beta$ knock-out mice. Journal of Endocrinology 166 R5-R9.

Orimo A, Inoue S, Ikegami A, Hosoi T, Akishita M, Ouchi Y, Muramatsu M \& Orimo H 1993 Vascular smooth muscle cells as target for estrogen. Biochemical Biophysical Research Communication 195 730-736.

Pelletier G, Labrie C \& Labrie F 2000 Localization of oestrogen receptor $\alpha$, oestrogen receptor $\beta$ and androgen receptors in the rat reproductive organs. Journal of Endocrinology 165 359-370.

Perrot-Applanat M, Groyer-Picard MT, Lorenzo F \& Milgrom E 1988 Immunocytochemical demonstration of estrogen and progesterone receptors in muscle cells of uterine arteries in rabbits and humans. Endocrinology 123 1511-1519.

Pettersson K, Grandien K, Kuiper GGJM \& Gustafsson J-Å 1997 Mouse estrogen receptor $\beta$ forms estrogen response element-binding heterodimers with estrogen receptor $\alpha$. Molecular Endocrinology 11 1486-1496.

Rosenfeld CR 1989 The uterine circulation. Ithaca, New York: Perinatology Press.

Rosenfeld CR, Cox BE, Roy T \& Magness RR 1996 Nitric oxide contributes to estrogen-induced vasodilation of the ovine uterine circulation. Journal of Clinical Investigation 98 2158-2166.

Saji S, Jensen EV, Nilsson S, Rylander T, Warner M \& Gustafsson J-Å 2000 Estrogen receptors $\alpha$ and $\beta$ in the rodent mammary gland. PNAS 97 337-342.

Saunders PTK, Maguire SM, Gaughan J \& Millar MR 1997 Expression of oestrogen receptor beta $(\mathrm{ER} \beta)$ in multiple rat tissues visualised by immunohistochemistry. Journal of Endocrinology 154 R13-R16.

Shi SR, Key ME \& Kalra KL 1991 Antigen retrieval in formalinfixed, paraffin embedded tissues: an enhancement method for immunohistochemical staining based on microwave oven heating of tissue sections. Journal of Histochemistry and Cytochemistry 39 741-748.

Taylor AH \& Al-Azzawi F 2000 Immunolocalisation of oestrogen receptor beta in human tissues. Journal of Molecular Endocrinology 24 145-155.

Van Buren GA, Yang DS \& Clark KE 1992 Estrogen-induced uterine vasodilatation is antagonized by L-nitroarginine methyl ester, an inhibitor of nitric oxide synthesis. American Journal of Obstetrics and Gynecology 167 828-833.

Received in final form 11 December 2000 Accepted 12 January 2001 